\title{
THE IMPACT OF GEOPOLITICAL RISKS ON FINANCIAL DEVELOPMENT: EVIDENCE FROM EMERGING MARKETS
}

\section{- Zhou Lu, Giray Gozgor, Mai Huang, Marco Chi Keung Lau}

\begin{abstract}
This paper aims to investigate the effect of geopolitical risks on financial development (measured by domestic credit to the private sector) in a panel dataset of 18 emerging markets over the period 1985-2018. The results from the fixed-effects estimations indicate that an increase in geopolitical risks leads to a lower level of domestic credit to the private sector. The findings from the bias-corrected least-squares dummy variable estimations also confirm that geopolitical risks impacts negatively on domestic credit to the private sector. In terms of controls, we have found that per capita income and broad money are positively associated with domestic lending. Further, external imbalances were found to suppress domestic credit in emerging markets. Various additional controls were then included to address potential omitted variable bias. Moreover, we utilized multiple robustness checks, such as excluding countries from different continents as well as extracting outlier observations. According to the findings from these robustness checks, the negative impact of geopolitical risks on domestic lending is statistically and economically robust. To the best of the author's knowledge, this paper is the first to provide evidence for the negative impact of geopolitical risks on financial development in emerging markets, the economic performance of which can slow down as competitiveness deceases due to concomitant threats.
\end{abstract}

Keywords: financial sector development, credits to the private sector, domestic lending, geopolitical risks, emerging markets, competitiveness, panel data methods

JEL Classification: E51, G21, G32, C33

Received: December, 2019

1st Revision: February, 2020

Accepted: February, 2020

\section{INTRODUCTION}

In the aftermath of the Global Financial Crisis of 2008-9, economic and political determinants of the financial sector credit have become an active area of research, as rapid domestic credit surge in an open economy is an acute symptom of potential financial crises along with instability in the financial sector (Obstfeld, 2012). Indeed, several emerging economies have experienced the "credit boom-bust cycles" since the early 1990s, with the significant growth of domestic credit seen as early-warning indicator of internal- and global financial crises (Davis et al., 2016; 
Gourinchas \& Obstfeld, 2012; Jordá et al., 2011; Schularick \& Taylor, 2012).

The importance of domestic credit in economic performance has been a well-known phenomenon since the early twentieth century thanks to the influential work of Joseph Schumpeter, whose History of Economic Analysis (1954) posits that the volume of credit in financial sectors is a keystone of economic growth. This hypothesis comes from Schumpeter's observation that investments of firms and the public sector, which are the origin of economic growth, are primarily financed by credit from the financial sector. Nevertheless, financial sector credit is not only the origin of investments, but it is also the leading catalyzer of consumption in emerging markets. In the light of these precepts, this paper aims to investigate the drivers of domestic credit to the private sector (henceforth DCPS) in a panel dataset of 18 emerging economies over the period 1985-2018. Specifically, we examine the impact of geopolitical risks via the recently-developed index of Geopolitical Risk (GPR) on the level of domestic financial sector credit in 18 emerging economies.

Examinations of the determinants of domestic credit have been rapidly increasing in the literature, but the driving factors of domestic credit growth remain unclear (Gozgor, 2018). As opposed to previous papers, the present study focuses on the impact of geopolitical risk on DCPS. Since the 1990s, emerging economies have undergone various events that have seen an increase in geopolitical risk, such as the so-called Arab Spring, Nuclear Tension related to Iran and to North Korea, the Russia-Ukraine Crisis of 2014, and the military insurgence in Syria. These geopolitical uncertainties can create a spillover effect on all developing and developed countries in the era of globalization.

The main challenge here is to define appropriate criteria that represents and measures geopolitical risk. Previous papers have used various risk indicators such as conflicts, terrorist attacks, wars or other indicators of political risk, with some studies applying measures of institutional quality such as levels of corruption, democratic institutions, government instability, influence on politics by the military, as well as legal culture and institutions.

The GPR index introduced by Caldara \& Iacoviello (2019) is used in our study. GPR shows a martix of risks based on the media coverage of geopolitical events by corporate news sources. Specifically, the index of the GPR focuses on the frequency (number of articles) related to geopolitical tensions in 11 leading newspapers from around the globe. Caldara \& Iacoviello (2019) consider articles related to military-related and nuclear tensions, acts of war, terrorist acts, as well as the threats of all of these potential risk factors to construct the GPR index. At this stage of our study, we have used GPR to investigate the effects of geopolitical risks on DCPS. Several papers in the previous literature have examined the impact of political risk on lending activity, but these studies have focused on survey-based measures of political risk. For example, Gozgor (2018) observes that worse socioeconomic conditions related to political risk (i.e., consumer confidence, poverty, and unemployment) and corruption are negatively associated with DCPS in a panel dataset of 61 developing economies over the period 1984-2016.

Previous papers have focused on the effects of GPR on business cycles, house prices, oil markets, gold prices, stock market dynamics, and trade volume. For example, after applying several panel data estimation techniques, Gupta et al. (2019) have recently found that the GPR is negatively 
associated with trade volumes in and among 164 countries over the period 1985-2013. Using a Structural Vector Autoregression (SVAR) model, Cheng \& Chiu (2018) have shown that shocks as measured by GPR can explain 13\%-22\% of output variations in 38 emerging markets. However, the possible impact of geopolitical risks on domestic credit seems to have been neglected by previous papers. In this paper, we aim to fill these gaps.

Likewise there is a need for further empirical research to enhance knowledge of the determinants of domestic credits in developing countries. For instance, we still do not know quantitatively the extent to which geopolitical risk affects domestic lending, nor the effects of geopolitical risks on domestic credit levels. To begin to address these questions, the present study focuses on 18 emerging economies on different continents over the period 1985-2018 using the new GPR index introduced by Caldara \& Iacoviello (2019) for information regarding domestic credits, along with various controls and varying panel data estimation procedures. To the best of the authors' knowledge, this is the first research study to quantitatively analyze the impacts of geopolitical risks via GPR on domestic credit, which is a benchmark measure of financial development. It has been observed that a high GPR factor is negatively associated with domestic loans in emerging economies. This evidence is also robust enough to instigate the investigation of various other indicators of domestic credits utilizing different estimation techniques. The paper also addresses potential problems of "omitted variable bias" and "endogeneity bias" in the estimations. It is anticipated that the empirical findings of this research will present essential policy implications regarding emerging economies.

The remainder of the study is defined as follows. Section 2 discusses the theoretical background and Section 3 explains the data and estimation procedures. Section 4 demonstrates the findings from various analyses as well as provides possible policy implications of the findings. Section 5 presents the conclusion.

\section{THEORETICAL BACKGROUND}

We suggest that geopolitical risk can significantly affect domestic credits via several channels. First, firms can postpone investments during periods of significant geopolitical risk, e.g., conflict events, military-related tensions, terrorist attacks, and war threats. Here, we suggest that firms in developing economies postpone their investments during the times of structural reforms due to policy uncertainties. Given that credit finances new ventures, this channel will affect the level of private loans. Second, consumers can lose confidence in the economy and government during periods of rising geopolitical risk, therefore they may postpone purchases of cars, durable goods, and residences, all purchases which are also primarily made with consumer loans and mortgages. Third, a higher level of geopolitical risk can hurt the democracy and investment profile of a country, since security concerns may affect freedom of personal security, movement and expression in times of military-related tensions, terrorist attacks, and war threats. Risk may lead to outflows of capital or a decline in capital inflows, meaning that the supply of domestic credit will be reduced.

Furthermore, private loans are a substitute for external borrowing in emerging economies. In times of increased geopolitical risks, financial institutions may reduce their risk appetite; and 
therefore, they want to lower their lending levels. At this stage, the countries which are open to financial globalization, can access foreign funds easier and can cover the adverse impacts of geopolitical risks on domestic credits. In short, geopolitical risks can negatively affect domestic loans via the channels of "firm investments," "household expenditures," "credit supply," and "substitution effect," respectively.

\section{RESEARCH OBJECTIVE, METHODOLOGY, AND DATA}

To estimate the effects of GPR on financial development in emerging economies, we consider several model specifications, which can be written as follows:

$$
\begin{aligned}
& D C_{i, t}=\alpha_{0}+\alpha_{1} G E P R_{\mathrm{i}, \mathrm{t}}+\alpha_{2} \mathrm{X}_{\mathrm{i}, \mathrm{t}}+\varepsilon_{1 \mathrm{i}, \mathrm{t}} \\
& D C_{i, t}=\beta_{0}+\beta_{1} G E P R_{i, \mathrm{t}-1}+\beta_{2} \mathrm{X}_{\mathrm{i}, \mathrm{t}}+\varepsilon_{2 \mathrm{i}, \mathrm{t}} \\
& D C_{i, t}=\gamma_{0}+\gamma_{1} D C_{i, \mathrm{t}-\mathrm{1}}+\gamma_{2} G E P \mathrm{R}_{i, \mathrm{t}}+\gamma_{3} \mathrm{X}_{\mathrm{i}, \mathrm{t}}+\varepsilon_{3 \mathrm{i}, \mathrm{t}}
\end{aligned}
$$

In Eq. (1), Eq. (2), and Eq. (3), $i=1 \ldots, 18$ represents countries; $t=1 . ., 33$ represents time dimension. $D C_{i, t}$ is the "domestic credit provided by the financial sector" relative gross domestic product (GDP). $D C_{i, t-1}$ is the lagged dependent, which indicates the persistency effect, i.e., maturity of credits longer than one year. $\log G E P R_{i, t}$ is the index of geopolitical risks. Also, the lagged value for the index of geopolitical risks $\log G P R_{i, t-1}$ is considered since geopolitical risks can decrease the level of domestic credits with a delaying effect. $X_{i, t}$ indicates control variables, which are considered by following previous literature (Gozgor, 2014). Per capita GDP represents the "income effect" (Moudud-Ul-Huq, 2019). Broad money supply indicates the "price effect" (Gozgor, 2018). The current account balance represents the extremal balance, i.e., the competitiveness of an economy. We also include various additional controls in the robustness analyses. $\alpha, \beta, \gamma$ are the estimated coefficients in different models, and $\varepsilon_{i, t}$ is the error-terms.

To estimate the models in Eq. (1), Eq. (2), and Eq. (3), we utilize fixed-effects and Least Squares Dummy Variable Corrected (LSDVC) estimations introduced by Bruno (2005). We consider the LSDVC estimations since the Generalized Method of Moment (GMM) method can provide biased evidence in the case of a small number of cross-sections (Bruno, 2005). Note that a "small number of cross-section" indicates that the case of the number of units is less than 20 . The fixedeffects estimator is a standard method to analyze the determinants of domestic credits (Magud et al., 2014). Following Gozgor \& Demir (2018), we control for both cross-sections fixed-effects and period fixed-effects to capture potential heterogeneities across countries. Besides, "robust standard errors," which are clustered at the country levels, are reported. The findings from the Hausman test also confirm the validity of the fixed-effects estimations. Note that we also determine the cross-sectional dependence among variables following the results of the cross-sectional dependence test of Pesaran (2004). After this evidence, we apply the test procedure of Pesaran (2007), and the related findings also demonstrate the stationarity of variables. The relevant findings did not report to save space.

On the other hand, the LSDVC estimations can solve a potential problem of "endogeneity bias" (i.e., the change in domestic credits can lead to geopolitical risks) by instrumenting geopolitical risks and lagged domestic loans. The LSDVC estimations can also address potential problems 
due to autocorrelation and unit root characteristics of explanatory variables. In the LSDVC estimations, the Arellano-Bond method is used as the benchmark bias correction method. We also check whether instruments are valid by running the Sargan test. The correlations between instruments and error terms, as well as instruments between instrumented variables, are reviewed by the Arellano-Bond autocorrelation tests of AR (1) and AR (2), respectively.

In this paper, we use the unbalanced panel data from 1985 to 2018 in 18 emerging economies. These 18 emerging economies are as follows: "Argentina, Brazil, China, Colombia, India, Indonesia, Israel, Korea (South), Malaysia, Mexico, Philippines, Russian Federation, Saudi Arabia, South Africa, Thailand, Turkey, Ukraine, and Venezuela." The selection of countries and the begging date of the empirical analysis are related to data availability of the GPR index. The dependent variable is the "domestic credit to the private sector (DCPS)" relative GDP. The data for DCPS is accessed from the World Bank (2020).

The primary variable of interest is the index of the GPR introduced by Caldara \& Iacoviello (2019). The yearly frequency data is created by taking the average of the monthly data of the GPR index. The GPR index is a news-based measure of risks related to geopolitical events. The index of the GPR focuses on the frequency (number of articles) related to geopolitical tensions in 11 international newspapers. Caldara \& Iacoviello (2019) consider articles related to six groups of words: Group 1 words explicitly indicate "geopolitical risk" and capture the "militaryrelated" tensions in large emerging economies and the United States. Group 2 words are based on "nuclear tensions." Group 3 and Group 4 words focus on events, which are related to "war threats" and "terrorist threats," respectively. Finally, Group 5 and Group 6 words are based on news, which is related to "terrorist acts" or a "starting of a war." These indices are constructed by Caldara \& Iacoviello (2019). The novelty of the index of the GPR comes from the fact that it is the first index to be constructed with a news-based approach in emerging economies (Demir et al., 2019). Therefore, the level of geopolitical risk is comparable across emerging economies after the introduction of the GPR index. We suggest that the contemporaneous index of the GPR should hurt DCPS, and actually, this is the central hypothesis in the paper. However, we also use the lagged GPR for avoiding a possible "reverse causality" issue, implying that DCPS can determine geopolitical risks. Note that this effect is not statistically significant in our empirical analyses. To the best of the authors' knowledge, the indices of the GPR have not previously used as a possible driver of DCPS. The main objective of this paper is to fill the related gap in the empirical literature.

We include various control variables in the empirical analyses. Following Gozgor (2014, 2018), per capita income (measured by constant 2010 \$ prices), broad money definition of money supply, and external balance (percentage of GDP) are considered as the main control variables in the panel data estimations. Here, per capita GDP and money supply, which capture the "income effect" and the "price effect," are expected to be positively associated with domestic credit provided to the private sector, respectively. As long as per capita GDP rises, the demand for loans will increas. At this stage, following Magud et al. (2014), we use the lagged measure of per capita GDP to avoid a possible "reverse causality," implying that credits are one of the determinants of economic growth (Samargandi \& Kutan, 2016). According to Guo \& Stepanyan (2011), a rise in the supply of money is a definition of the expansionary monetary stance, and this indicator 
should positively affect the DCPS. The external balance captures the open-economy form of the credit-supply model (Takats, 2010), and it can model the effects of the relationship between other countries and the competitiveness with the world on the supply of domestic credits (Lane \& McQuade, 2014). A lower current account deficit in an emerging economy shows that there is a higher level of savings, implying that a higher supply of credits (Gozgor, 2018). According to Obstfeld (2012), borrowing at the higher interest rates will affect exchange, and inflation rates can increase in emerging economies. Following these potential determinants of domestic credits, we also use interest rates (measured by deposit rate and lending rate), inflation (measured by the consumer price index), and exchange rate against the USD in the estimations. Besides, a stable economic performance, which is regulated by the yearly growth rate of GDP, can positively affect the level of domestic credits (Elekdag \& Han, 2015). The data of these variables are also downloaded from World Bank (2020).

Furthermore, economic globalization may significantly affect domestic credit levels since there is a substantive impact of economic globalization on the volumes of domestic credit via real exchange rates, international capital flows, and monetary policy transmission channels (Lane \& McQuade, 2014). To this end, we use the index of economic globalization, which is reported by the KOF Swiss Economic Institute. Dreher (2006) has introduced the KOF indices of globalization initially, and Gygli et al. (2019) have revisited it by including various new dimensions of economic globalization, and for details, refer to the web site of KOF. Besides, trade openness directly affects domestic credit levels in emerging economies (Gozgor, 2018). Here, we use the real trade openness measure in Feenstra et al. (2015), which is defined as (imports + exports)/ GDP in the PPP prices as a potential driver of domestic credit provided to the private sector. For more information, see https://www.rug.nl/ggdc/productivity/pwt/. A summary of descriptive statistics for all of these variables is presented in Table 1. Our dataset provides an unbalanced panel dataset, and we have only used the dates and the countries, where all controls are available.

We also provide the correlation matrix for the variables in benchmark regressions in Table 2 . The correlations between the domestic credit measure and the index of the GPR is -0.066 , implying that there is a negative and weak relationship between the related variables. There are also positive correlations among the dependent and control variables.

\section{RESULTS AND DISCUSSION}

\subsection{Fixed-Effects Estimations}

In Table 3, we report the results of fixed-effects estimations for the model in Eq. (1), Eq. (2), and Eq. (3), where the DCPS is the dependent variable.

Tab. 1 - descriptive summary statistics (1985-2018). Source: Feenstra et al. (2015); Gygli et al. (2019); World Bank (2020)

\begin{tabular}{|l|l|l|l|l|l|}
\hline Variables & Average & Std. Dev. & Min. & Max. & Obs. \\
\hline DCPS (\% of GDP) & 57.40 & 41.82 & 1.385 & 166.5 & 563 \\
\hline
\end{tabular}




\begin{tabular}{|l|l|l|l|l|l|}
\hline $\begin{array}{l}\text { Per Capita GDP (Constant 2010 USD) } \\
(\text { Log) }\end{array}$ & 8.697 & 0.927 & 6.183 & 10.45 & 602 \\
\hline Broad Money (\% of GDP) & 61.68 & 37.72 & 10.55 & 209.4 & 580 \\
\hline Current Account Balance (\% of GDP) & 0.556 & 5.597 & -20.80 & 27.39 & 590 \\
\hline Inflation, Consumer Prices (Annual \%) & 46.01 & 286.9 & -3.203 & 4734 & 534 \\
\hline $\begin{array}{l}\text { Official Exchange Rate (LCU per US\$) } \\
\text { (Log) }\end{array}$ & 2.322 & 3.618 & -19.73 & 10.42 & 589 \\
\hline Deposit Interest Rate (\%) & 110.2 & 963.4 & 0.457 & 17235 & 495 \\
\hline Lending Interest Rate (\%) & 17.63 & 19.67 & 3.367 & 250.2 & 470 \\
\hline Annual GDP Growth (\%) & 3.193 & 4.824 & -22.93 & 18.28 & 600 \\
\hline Real Trade Openness & 49.29 & 13.80 & 13.90 & 78.10 & 583 \\
\hline Economic Globalization Index (Log) & 0.374 & 0.248 & 0.031 & 1.227 & 584 \\
\hline GPR (Log) & 4.554 & 0.275 & 3.576 & 5.565 & 612 \\
\hline
\end{tabular}

Tab. 2 - correlation matrix (1985-2018). Source: own research

\begin{tabular}{|l|l|l|l|l|l|}
\hline Regressors & DCPS & $\begin{array}{l}\text { Per Capita } \\
\text { Income (Log) }\end{array}$ & $\begin{array}{l}\text { Broad } \\
\text { Money }\end{array}$ & $\begin{array}{l}\text { External } \\
\text { Balance }\end{array}$ & $\begin{array}{l}\text { GPR } \\
\text { (Log) }\end{array}$ \\
\hline DCPS & 1.000 & - & - & - & - \\
\hline Per Capita Income (Log) & 0.092 & 1.000 & - & - & - \\
\hline Broad Money & 0.832 & 0.043 & 1.000 & - & - \\
\hline External Balance & 0.138 & 0.143 & 0.230 & 1.000 & - \\
\hline GPR (Log) & -0.066 & 0.004 & 0.061 & 0.155 & 1.000 \\
\hline
\end{tabular}

The findings of contemporaneous measures of the GPR are provided in Columns (I), (III), and $(\mathrm{V})$, and the results for lagged measures of the GPR are reported in Columns (II), (IV), and (VI). All findings show that both contemporaneous and lagged measures of the GPR reduce the DCPS. However, the coefficients of the lagged GPR index are statistically insignificant in the conclusions from columns (IV) and (VI). All of these results indicate a rise in the GPR index associated with the lower DCPS. When we look at the magnitudes of the impact in the baseline model provided in Column (V), we find that a 1\% increase in the GPR index leads to a $2.79 \%$ reduction in the level of the DCPS.

When we look at the effects of control variables on the DCPS in the baseline model provided in Column (V), we observe that the per capita income and broad money are positively associated with DCPS. Furthermore, the external balance is negatively related to DCPS. There is also a medium-level of persistence in DCPS since the coefficient of the lagged DCPS is statistically significant, and it is obtained as 0.72 . The findings of the Hausman test also show that the fixedeffects estimations are consistent. 
Tab. 3 - Results of the fixed-effects estimations (1985-2018). Source: own research

\begin{tabular}{|c|c|c|c|c|c|c|}
\hline Variable & (I) & (II) & (III) & (IV) & $(\mathrm{V})$ & $(\mathrm{VI})$ \\
\hline Intercept & $\begin{array}{l}78.53^{* * *} \\
(16.52)\end{array}$ & $\begin{array}{l}89.53^{* * *} \\
(16.83)\end{array}$ & $\begin{array}{l}19.61 * * * \\
(6.873)\end{array}$ & $\begin{array}{l}15.74 * * \\
(7.040)\end{array}$ & $\begin{array}{l}47.66^{* * *} \\
(14.82)\end{array}$ & $\begin{array}{l}40.20^{* * *} \\
(14.59)\end{array}$ \\
\hline $\begin{array}{l}\text { Lagged } \\
\text { DCPS }\end{array}$ & - & - & $\begin{array}{l}0.906^{* * *} \\
(0.017)\end{array}$ & $\begin{array}{l}0.905^{* * *} \\
(0.017)\end{array}$ & $\begin{array}{l}0.722 * * * \\
(0.022)\end{array}$ & $\begin{array}{l}0.723 * * * \\
(0.022)\end{array}$ \\
\hline $\begin{array}{l}\text { Lagged Per } \\
\text { Capita GDP } \\
(\mathrm{Log})\end{array}$ & - & - & - & - & $\begin{array}{l}4.428 * * * \\
(1.691)\end{array}$ & $\begin{array}{l}4.267^{* *} \\
(1.696)\end{array}$ \\
\hline $\begin{array}{l}\text { Money Sup- } \\
\text { ply }\end{array}$ & - & - & - & - & $\begin{array}{l}0.324 * * * \\
(0.031)\end{array}$ & $\begin{array}{l}0.320^{* * *} \\
(0.031)\end{array}$ \\
\hline $\begin{array}{l}\text { Current } \\
\text { Account } \\
\text { Balance }\end{array}$ & - & - & - & - & $\begin{array}{l}-0.330^{* * *} \\
(0.064)\end{array}$ & $\begin{array}{l}-0.344^{* * *} \\
(0.064)\end{array}$ \\
\hline GPR (Log) & $\begin{array}{l}-4.546^{* * *} \\
(1.529) \\
\end{array}$ & - & $\begin{array}{l}-2.903^{* *} \\
(1.338)\end{array}$ & - & $\begin{array}{l}-2.792 * * \\
(1.350)\end{array}$ & - \\
\hline $\begin{array}{l}\text { Lagged GPR } \\
(\log )\end{array}$ & - & $\begin{array}{l}-6.950^{*} \\
(3.695)\end{array}$ & - & $\begin{array}{l}-2.046 \\
(1.519)\end{array}$ & - & $\begin{array}{l}-1.421 \\
(1.385)\end{array}$ \\
\hline $\begin{array}{l}\text { Observa- } \\
\text { tions }\end{array}$ & 563 & 547 & 541 & 541 & 540 & 540 \\
\hline $\begin{array}{l}\text { Number of } \\
\text { Countries }\end{array}$ & 18 & 18 & 18 & 18 & 18 & 18 \\
\hline $\begin{array}{l}\text { Hausman } \\
\text { Test }\end{array}$ & $34.4[0.000]$ & $33.8[0.000]$ & $41.3[0.000]$ & $42.1[0.000]$ & $35.6[0.000]$ & $33.2[0.000]$ \\
\hline $\begin{array}{l}\text { R-squared } \\
\text { (Within) }\end{array}$ & 0.003 & 0.006 & 0.836 & 0.836 & 0.873 & 0.872 \\
\hline
\end{tabular}

Notes: The dependent variable is the DCPS. According to the results of the Hausman test, the fixed-effects estimations are consistent. () represents standard errors at the country level and [] represents probability values. $* * * \mathrm{p}<0.01, * * \mathrm{p}<0.05$, and $* \mathrm{p}<0.10$.

Overall, our findings indicate that the GPR index reduces the DCPS, and this finding is in line with our central hypothesis. This finding is also the first evidence in the literature to show the significant adverse impacts of geopolitical risks on domestic credits, i.e., the baseline measure of financial development. In the next subsection, we discuss our findings with possible implications.

\subsection{Results Of The LSDVC Estimations}

In Table 4 we provide the results of the LSDVC estimations for the benchmark model in Eq. (3), where the dependent variable is the DCPS. Note that the LSDVC estimations automatically include the lagged measure of the dependent variable. Also, the lagged coefficients of the explanatory variables cannot be used in the LSDVC estimations, which is why we solely consider the model in Eq. (3), with the models in Eq. (1) and Eq. (2) automatically dropped. 
Tab. 4 - Results of the LSDVC estimations (1985-2018). Source: own research

\begin{tabular}{|l|l|l|}
\hline Variable & $(\mathrm{I})$ & $(\mathrm{II})$ \\
\hline Lagged DCPS & $0.966^{* * *}(0.023)$ & $0.769^{* * *}(0.020)$ \\
\hline Log Per Capita GDP & - & $4.825^{* * *}(1.594)$ \\
\hline Money Supply & - & $0.294^{* * *}(0.027)$ \\
\hline Current Account Balance & - & $-0.318^{* * *}(0.079)$ \\
\hline GPR (Log) & $-2.907^{* * *}(0.638)$ & $-2.807 * * *(0.592)$ \\
\hline Observations & 541 & 540 \\
\hline Number of Countries & 18 & 18 \\
\hline AR (1) Test Statistic and p-value & $-3.05[0.000]$ & $-3.38[0.000]$ \\
\hline AR (2) Test Statistic and p-value & $-0.43[0.395]$ & $-0.51[0.312]$ \\
\hline Sargan Test Statistic and p-value & $119.2[0.793]$ & $123.5[0.814]$ \\
\hline
\end{tabular}

Notes: The dependent variable is the DCPS. () represents standard errors at the country level and [ ] represents probability values. $* * * \mathrm{p}<0.01$.

Here, we consider a different estimation procedure rather than fixed-effects estimations. Our main objective, however, is to address a possible "endogeneity bias," i.e. a "reverse causality" problem may exist and the DCPS may affect the GPR index. The results from the panel Granger causality analyses also show that no problem of reverse causality is indicated. Overall, the LSDVC estimations can solve potential problems of "endogeneity bias" and "reverse causality."

The findings of the diagnostics show that the necessary assumptions for the efficient estimation procedure are satisfied. According to the findings of the Sargan test, there is no "over-identification problem" in the LSDVC estimations, and consistent with the autocorrelation test for the AR(1) and $\mathrm{AR}(2)$ models, a significant first-order autocorrelation is indicated, whereas the second-order autocorrelation is statistically insignificant.

The baseline results in Column (II) indicate that there is a moderate persistence in the DCPS. This finding is in line with the fixed-effects estimations. Furthermore, the outcomes of the contemporaneous measure of the GPR index is negatively associated with the DCPS. In terms of control variables, we find that income and broad money positively affect the DCPS, but the external balance is negatively related to the DCPS. Overall, all the findings for the LSDVC estimations are in line with the benchmark fixed-effects estimations.

\subsection{Inclusion of Additional Controls}

In Table 5, we provide the results of additional sensitivity analyses and include different controls to the benchmark model in Eq. (3), where the DCPS is the dependent variable.

Tab. 5 - Fixed-effects estimations (1985-2018) (including controls). Source: own research

\begin{tabular}{|l|l|l|}
\hline Robustness Check & Variable & Coefficient \\
\hline Results of the Benchmark Regressions & GPR $(\mathrm{Log})$ & $-2.792^{* *}(1.350)$ \\
\hline Including Inflation Rate & GPR $(\mathrm{Log})$ & $-3.189^{* *}(1.509)$ \\
\hline Including Official Exchange Rate & GPR $(\mathrm{Log})$ & $-2.742^{* *}(1.357)$ \\
\hline
\end{tabular}




\begin{tabular}{|l|l|l|}
\hline Including Deposit Interest Rate & GPR $(\mathrm{Log})$ & $-2.808^{* *}(1.415)$ \\
\hline Including Lending Interest Rate & GPR $(\mathrm{Log})$ & $-3.630^{* * *}(1.223)$ \\
\hline Including Annual GDP Growth & GPR $(\mathrm{Log})$ & $-2.551^{* *}(1.244)$ \\
\hline Including Real Trade Openness & GPR $(\mathrm{Log})$ & $-2.675^{* *}(1.314)$ \\
\hline Including Economic Globalization Index & GPR $(\mathrm{Log})$ & $-2.851^{* *}(1.421)$ \\
\hline
\end{tabular}

Notes: The dependent variable is the DCPS. Main controls are included, but they are not reported. () represents standard errors at the country level. $* * * \mathrm{p}<0.01$ and $* * \mathrm{p}<0.05$.

The results in Table 5 encompass the benchmark model provided in Table 3, Column 5 in which the sensitivity analysis consider as the main control variables the lagged DCPS, lagged per capita income, money supply, and the external balance. This sensitivity analysis includes additional control variables to address a possible "omitted variable bias." According to the previous papers, other determinants of the DCPS may be indicated, e.g. annual GDP growth, economic globalization, exchange rate, inflation rate, interest rate, as well as international trade could all be significant determinants of the DCPS in emerging economies (Bakker \& Gulde, 2010; Elekdag \& Han, 2015; Gozgor, 2018; Gozgor et al., 2019; Luca \& Spatafora, 2012).

At this stage, we separately added these variables to the benchmark estimations in Table 3, Column $\mathrm{V}$, a procedure which provided findings which are in line with the baseline estimations, i.e. a higher level in the GPR negatively associated with the level of DCPS. Overall, the benchmark evidence remains robust when additional controls are included. The GPR index has a negative sign, and the coefficients are statistically significant in each scenario in Table 5.

\subsection{Robustness to the Outliers}

In Table 6, we provide the results of other robustness checks, excluding outlier observations and countries in different regions and with different income levels. The results reported here are based on fixed-effects estimations, where the dependent variable is the DCPS.

First, we extracted the outlier observations of loans offered by the financial sector and the GPR. Following Bergh \& Nilsson (2010) and Gozgor (2018), we define "outliers" as observations, which are higher and lower than the interval: "average $\pm 2 *$ standard deviation." According to the findings in Table 6, the results are robust enough to extract outliers from the dataset.

Tab. 6 - Fixed-effects estimations (1985-2018) (excluding outliers). Source: own research

\begin{tabular}{|l|l|l|}
\hline Robustness Check & Variable & Coefficient \\
\hline Results of the Benchmark Regressions & GPR $(\mathrm{Log})$ & $-2.792^{* *}(1.350)$ \\
\hline Extracting the Outliers of DCPS & GPR $(\mathrm{Log})$ & $-2.791^{* *}(1.351)$ \\
\hline Extracting the Outliers of Index of Geopolitical Risks & GPR $(\mathrm{Log})$ & $-2.110^{* *}(1.083)$ \\
\hline Extracting High-income Economies & GPR $(\mathrm{Log})$ & $-1.416^{* *}(0.681)$ \\
\hline Extracting Middle East Economies & GPR $(\mathrm{Log})$ & $-1.920^{* *}(0.905)$ \\
\hline Extracting Latin American Economies & GPR $(\mathrm{Log})$ & $-1.752^{* * *}(0.566)$ \\
\hline Extracting East Asia Economies & GPR $(\mathrm{Log})$ & $-1.864^{* * *}(0.712)$ \\
\hline
\end{tabular}

Notes: The dependent variable is the DCPS. Main controls are included, but they are not reported. () represents standard errors at the country level. $* * * \mathrm{p}<0.01$ and $* * \mathrm{p}<0.05$. 
Second, we determined whether our findings are sensitive enough to extract some countries from the dataset. To this end, we extracted high-income economies (Israel, Saudi Arabia, and South Korea), then separately extracted countries in different regions, such as East Asia (China, Indonesia, Malaysia, Philippines, South Korea, and Thailand), Latin America (Argentina, Brazil, Colombia, Mexico, and Venezuela), and Middle East (Israel and Saudi Arabia). We revisited the fixed-effects estimations by extracting countries according to these different scenarios. The results show that the negative impact of geopolitical risk on domestic credit is robust enough to implement these robustness checks, meaning that certain countries in the dataset do not drive the primary evidence.

In short, after various robustness analyses, we continue to observe that the GPR index negatively affected financial sector credit in 18 emerging economies over the period 1985-2018. Individually, first, we considered different periods. Second, we considered different model specifications. Third, we included various controls to address a possible "omitted variable bias." Fourth, we utilized different estimations procedures to discuss a potential "endogeneity bias." Fifth, we extracted the outliers and countries in terms of different income level and region. We can therefore suggest that the impact of geopolitical risk on financial sector development is financially and statistically robust.

\section{DISCUSSION AND IMPLICATIONS}

The baseline evidence in this paper shows that geopolitical risk is negatively associated with financial sector credit. This finding is in some ways similar to the result provided by Bordo et al. (2016), who found a harmful impact of economic policy uncertainty on bank lending decisions. The novelty of our paper is that is shows the detrimental effects of geopolitical risk on domestic credit in 18 emerging economies.

Financial sector credit is considered a primary method of funding the investments of private firms and government enterprises. Previous papers have indicated that during high-risk intervals, firms tend to delay investments until less risky periods or to cancel them altogether. Suspending investments due to geopolitical risk can also be related to a lack of financial sources. The financial sector can decrease lending opportunities to firms, since financiers may be skeptical about investment return and default-risk from loans. In short, geopolitical risk can limit the supply of loans, and this stifles investment. As a consequence, the level of economic performance in emerging countries could fall due to the lower level of competitiveness in terms of financial development.

Governments can provide extra funding to firms in times of high geopolitical risks, and they can give direct support toward financing investments to sustain economic performance. In addition, governments can originate alternative credit tools to firms with lower funding rates and to provide a longer-term for credit repayment. Providing extra funding to firms can decrease the negative impact of geopolitical risk on domestic lending, a policy which can also help accelerate economic performance.

In terms of households, the demand for credit to purchase cars, houses and high-end items will decrease in times of high geopolitical risk. Increased household credit can also support economic 
performance, although geopolitical risk can slow down economic activity with though the credit channel. At this stage, governments can provide extra benefits for households to promote the level of domestic credit. If there is a rise in the GPR index, public financial institutions can notably enhance the availability of funds. However, this policy implication can work only in the short-run, whereas in the longer term, public orders create stability and transparency in terms of economic policies.

With regards to firms, they need to monitor global and regional events which can cause or exacerbate geopolitical risk. During times of geopolitical threat, firms can hold more cash against tightening credit conditions (Demir \& Ersan, 2017). Given that external funding is a substitute for domestic credit, domestic firms can attempt to borrow from international markets to finance projects during periods of geopolitical risk.

\section{CONCLUSION}

In this paper, we have examined the impact of geopolitical risk and uncertainty via a new index, the so-called GPR, on financial sector credit in 18 emerging economies over the period 1985-2018. We ran fixed-effects and LSDVC estimations and observe that a higher value in the GPR index reduces the domestic credit provided by the financial sector. While per capita GDP and broad money promote financial sector credit, a higher level of external imbalance restrains credit. We have also implemented various robustness checks, including several additional controls and excluding outliers, and our main findings remain statistically robust. It is important to note that the GPR index is limited by its appearing only monthly. Future studies can apply timeseries estimation procedures to analyze the effects of geopolitical risk on financial indicators in each emerging economy in the dataset.

\section{Acknowledgements}

The authors thank the National Social Science Fund of China (17XJY008) and the Natural Science Foundation of Zhejiang Province, China (LZ20G010002) for their support.

\section{References}

1. Bakker, B., \& Gulde, A. (2010). The Credit Boom in the EU New Member States: Bad Luck or Bad Policies? International Monetary Fund Working Paper, No. 10/130. Washington, D.C.: International Monetary Fund.

2. Bergh, A., \& Nilsson, T. (2010). Do Liberalization and Globalization Increase Income Inequality? European Journal of Political Economy, 26 (4), 488-505. https://doi.org/10.1016/j. ejpoleco.2010.03.002

3. Bordo, M.D., Duca, J.V., \& Koch, C. (2016). Economic Policy Uncertainty and the Credit Channel: Aggregate and Bank Level U.S. Evidence over Several Decades. Journal of Financial Stability, 26(1), 90-106. https://doi.org/10.1016/j.jfs.2016.07.002

4. Bruno, G.S.F. (2005). Estimation and Inference in Dynamic Unbalanced Panel Data Models with a Small Number of Individuals. Stata Journal, 5 (4), 473-500. https://doi. org/10.1177/1536867X0500500401 
5. Caldara, D., \& Iacoviello, M. (2019). Measuring Geopolitical Risk. FRB International Finance Discussion Paper, No. 1222, December 2019, Washington, D.C: The Federal Reserve Board of Governors.

6. Cheng, C.H.J., \& Chiu, C.W.J. (2018). How Important Are Global Geopolitical Risks to Emerging Countries? International Economics, 156 (1), 305-325. https://doi.org/10.1016/j. inteco.2018.05.002

7. Davis, J.S., Mack, A., Phoa, W., \& Vandenabeele, A. (2016). Credit Booms, Banking Crises, and the Current Account. Journal of International Money and Finance, 60 (1), 360-377. https:// doi.org/10.1016/j.jimonfin.2015.09.008

8. Demir, E., \& Ersan, O. (2017). Economic Policy Uncertainty and Cash Holdings: Evidence from BRIC Countries. Emerging Markets Review, 33 (1), 189-200. https://doi.org/10.1016/j. ememar.2017.08.001

9. Demir, E., Gozgor, G., \& Paramati, S.R. (2019). Do Geopolitical Risks Matter for Inbound Tourism? Eurasian Business Review, 9 (2), 183-191. https://doi.org/10.1007/s40821-01900118-9

10. Dreher, A. (2006). Does Globalization Affect Growth? Evidence from a New Index of Globalization. Applied Economics, 38 (10), 1091-1110. https://doi. org/10.1080/00036840500392078

11. Elekdag, S., \& Han, F. (2015). What Drives Credit Growth in Emerging Asia? Journal of Asian Economics, 38, 1-13. https://doi.org/10.1016/j.asieco.2015.03.001

12. Feenstra, R.C., Inklaar, R., \& Timmer, M.P. (2015). The Next Generation of the Penn World Table. American Economic Review, 105 (10), 3150-3182. https://doi.org/10.1257/ aer.20130954

13. Gourinchas, P-O., \& Obstfeld, M. (2012). Stories of the Twentieth Century for the Twentyfirst. American Economic Journal: Macroeconomics, 4 (1), 226-265. https://doi.org/10.1257/ mac.4.1.226

14. Gozgor, G. (2014). Determinants of Domestic Credit Levels in Emerging Markets: The Role of External Factors. Emerging Markets Review, 18, 1-18. https://doi.org/10.1016/j. ememar.2013.11.003

15. Gozgor, G. (2018). Determinants of the Domestic Credits in Developing Economies: The Role of Political Risks. Research in International Business and Finance, 46 (1), 430-443. https:// doi.org/10.1016/j.ribaf.2018.05.002

16. Gozgor, G. \& Demir, E. (2018). Effects of the Economic Policy Uncertainty on Outbound Travel Expenditures. Journal of Competitiveness, 10 (3), 5-15. https://doi.org/0.7441/ joc. 2018.03 .01

17. Gozgor, G., Demir, E., Belas, J., \& Yesilyurt, S. (2019). Does Economic Uncertainty Affect Domestic Credits? An Empirical Investigation. Journal of International Financial Markets, Institutions, and Money, 63 (1), 101-147. https://doi.org/10.1016/j.intfin.2019.101147

18. Guo, K., \& Stepanyan, V. (2011). Determinants of Bank Credit in Emerging Market Economies. International Monetary Fund Working Paper, No. 11/51. Washington, D.C.: International Monetary Fund. 
19. Gupta, R., Gozgor, G., Kaya, H., \& Demir, E. (2019). Effects of Geopolitical Risks on Trade Flows: Evidence from the Gravity Model. Eurasian Economic Review, 9 (4), 515-530. https://doi.org/10.1007/s40822-018-0118-0

20. Gygli, S., Haelg, F., Potrafke, N., \& Sturm, J-E. (2019). The KOF Globalisation IndexRevisited. The Review of International Organizations, 14 (3), 543-574. https://doi.org/10.1007/ s11558-019-09344-2

21. Jordá, O., Schularick, M., \& Taylor, A.M. (2011). Financial Crises, Credit Booms, and External Imbalances: 140 Years of Lessons. IMF Economic Review, 59 (2), 340-378. https:// doi.org/10.1057/imfer.2011.8

22. Lane, P.R., \& McQuade, P. (2014). Domestic Credit Growth and International Capital Flows. Scandinavian Journal of Economics, 116 (1), 218-252. https://doi.org/10.1111/sjoe.12038

23. Luca, O., \& Spatafora, N. (2012). Capital Inflows, Financial Development, and Domestic Investment: Determinants and Inter-relationships. International Monetary Fund Working Paper, No. 12/120. Washington, D.C.: International Monetary Fund.

24. Magud, N.E., Reinhart, C.M., \& Vesperoni, E.R. (2014). Capital Inflows, Exchange Rate Flexibility, and Credit Booms. Review of Development Economics, 18 (3), 415-430. https://doi. org $/ 10.1111 /$ rode. 12093

25. Moudud-Ul-Huq, S. (2019). Banks' Capital Buffers, Risk, and Efficiency in Emerging Economies: Are they Counter-cyclical? Eurasian Economic Review, 9 (4), 467-492. https://doi. org $/ 10.1007 / \mathrm{s} 40822-018-0121-5$

26. Obstfeld, M. (2012). Does the Current Account Still Matter? American Economic Review, 102 (3), 1-23. https://doi.org/10.1257/aer.102.3.1

27. Pesaran, M.H. (2004). General Diagnostic Tests for Cross Section Dependence in Panels. IZA Discussion Paper, No. 1240. Bonn: IZA.

28. Pesaran, M.H. (2007). A Simple Panel Unit Root Test in the Presence of Cross-section Dependence. Journal of Applied Econometrics, 22 (2), 265-312. https://doi.org/10.1002/jae.951

29. Samargandi, N., \& Kutan, A.M. (2016). Private Credit Spillovers and Economic Growth: Evidence from BRICS Countries. Journal of International Financial Markets, Institutions, and Money, 44 (1), 56-84. https://doi.org/10.1016/j.intfin.2016.04.010

30. Schularick, M., \& Taylor, A.M. (2012). Credit Booms Gone Bust: Monetary Policy, Leverage Cycles, and Financial Crises, 1870-2008. American Economic Review, 102 (2), 1029-1061. https://doi.org/10.1257/aer.102.2.1029

31. Takats, E. (2010). Was it Credit Supply? Cross-border Bank Lending to Emerging Market Economies during the Financial Crisis. Bank for International Settlements Quarterly Review, $2,49-56$.

32. World Bank (2020). World Development Indicators Dataset. Washington, D.C.: World Bank. 


\section{Contact information}

prof. Zhou Lu, Ph.D.

Tianjin University of Commerce,

School of Economics

China

E-mail:luzhou59@tjcu.edu.cn

ORCID: 0000-0001-6004-6754

prof. Giray Gozgor, Ph.D.

Istanbul Medeniyet University

Faculty of Political Sciences

Turkey

E-mail:giray.gozgor@medeniyet.edu.tr

ORCID: 0000-0003-1238-8105

prof. Mai Huang, Ph.D.

(Corresponding Author)

Chongqing Technology and Business University

School of Business

China

E-mail:pkubm@126.com

ORCID:0000-0001-9310-9926

prof. Marco Chi Keung Lau, Ph.D.

The University of Huddersfield

Huddersfield Business School

United Kingdom

E-mail:c.lan@bud.ac.uk

ORCID: 0000-0002-2430-5592 